\title{
AMERICAN TELEMEDICINE ASSOCIATION: 18TH ANNUAL INTERNATIONAL MEETING \& TRADESHOW
}

\section{AUSTIN, TEXAS, MAY 4-7, 2013.}

BENJAMIN FORSTAG

For 18 years, the American Telemedicine Association (ATA) Annual International Meeting \& Exposition has been the premier forum for professionals in telemedicine, telehealth and mHealth -- and is one of the fastest growing meetings in the country. ATA 2013 is on course to be the largest ATA meeting ever, with over 6,000 projected attendees.

The program will include 500 educational sessions and posters, highlighting the latest innovations, applications and research in telemedicine. The 2013 exhibit hall will feature nearly 300 of the leading vendors in remote healthcare technologies.

Detailed program information--including courses, sessions and CME information--will be available January 2013 at: http://www.americantelemed.org. 
